\section{Iniquities in the access to renal transplant for patients with end-stage chronic renal disease in Brazil}

\author{
Iniquidades no acesso ao transplante renal \\ para pacientes com doença renal crônica \\ terminal no Brasil
}

Elaine Leandro Machado 1 Waleska Teixeira Caiaffa ${ }^{1}$ Cibele Comini César 2 Isabel Cristina Gomes 2 Eli Iola Gurgel Andrade 1 Francisco de Assis Acúrcio 1 Mariangela Leal Cherchiglia 1

\section{Introduction}

The objective of this present study is to analyze individual and contextual factors associated with access to renal transplant in Brazil. An observational, prospective and non-concurrent study was carried out, based on data from the National Database on renal replacement therapies in Brazil. Patients undergoing dialysis between 01/Jan/2000 and 31/Dec/2000 were included and monitored up to the point of transplant, death or until the end of the study period. Variables that were analyzed included: individual variables (age, sex, region of residence, primary renal disease, hospitalizations); and context variables concerning both the dialysis unit (level of complexity, juridical nature, hemodialysis machines and location) and the city (geographic region, location and HDI). Proportional hazard models were adjusted with hierarchical entry to identify factors associated with the risk of transplant. The results point to differentials in access according to socio-demographic, clinical, geographic and social factors, indicating that the organ allocation system has not eliminated avoidable disparities for those who compete for an organ in the nationwide waiting list.

Kidney Transplantation; Health Inequalities; Accessibility to Health Services; Chronic Kidney Failure
Chronic kidney disease is a worldwide public health problem that reduces life expectancy and typically progresses to end-stage chronic renal disease and a need for renal replacement therapy ${ }^{1}$. The renal replacement therapies available are dialysis (hemodialysis and peritoneal dialysis) and renal transplant. Renal transplantation is preferred over dialysis for the treatment of many patients with end-stage chronic renal disease because it improves both survival and quality of life, reducing long-term costs of care 2,3,4 .

In absolute numbers of kidney transplantations, Brazil ranks second among all countries, after the United States, and ranks ninth when corrected per million inhabitants 5 . The Brazilian Unified National Health System (SUS) ${ }^{6}$ pays for more than $95 \%$ of transplants performed in the country ${ }^{5}$, and provides the necessary post-transplant medication and follow-up, representing a growing demand upon public resources 7 .

Previous studies have showed disparities in the access to kidney transplant. These discrepancies are mainly attributed to individual sociocultural variables (race/ethnicity, sex, age, educational level, social support networks and personal beliefs); socioeconomic factors (income, private health insurance), and clinical conditions (comorbid, time on dialysis, histocompatibility, blood type, access to primary health care and late referral to a nephrologist) $8,9,10,11,12,13,14,15$. 
Contextual characteristics related to the dialysis units and transplant centers, in addition to the patient's area of residence and neighborhood poverty have also been associated with the probability of access to transplant 8,16,17,18.

In Brazil, despite the existence of a National Policy of Care to Patients with Renal Disease ( $D e$ cree $n^{o} .1,168$ of $15 / \mathrm{Jul} / 2004$ ) that assures coverage and equity in the performance of renal transplant 19 , auditing reports have shown unequal access to renal transplant, mainly for low-income populations, and those without private health insurance or who live in remote areas that are far from transplant centers 20 . However, there are no nationwide studies 7 that evaluate access to kidney transplantation.

One possibility is the use of information obtained by administrative data systems related to the SUS registry of payments for medical procedures for patients under renal replacement therapy. The databases have been used to answer relevant questions about epidemiological profiles in the area of chronic renal disease 21,22.

The social relevance of transplants, as well as the absence of nationwide studies that analyse the individual and contextual determinants that generate iniquities in the access to renal transplant, justify this investigation. The present study describes and analyzes, using various database sources, the socio-demographic, clinical and contextual factors associated with access to renal transplant in Brazil.

\section{Methods}

This is an observational, prospective non-concurrent-type study, part of a project entitled Project Renal Replacement Therapy - Economic-epidemiological Assessment of Renal Replacement Therapies in Brazil conducted by the Research Group on Health Economics at the Federal University of Minas Gerais 21. The main result of this project was the development of a National Database for Renal Replacement Therapy by means of the deterministic-probabilistic relationship technique based on the following Public Health System databases: (1) High Complexity/Cost Procedures Authorization System (APAC) from the Ambulatory Information System (SIA); (2) Hospital Information Systems (SIH); and (3) Mortality Information System (SIM). The objective in building this database was to complement the APAC information, with data on hospitalizations from the SIH and mortality data from the SIM, allowing for the follow up of a cohort of patients involved in renal replacement therapy between the years 2000 and 200421,22 .
For this study, the population included all individuals registered in the National Database for renal replacement therapy, who underwent dialysis between 01/Jan/2000 and 31/Dec/2000, with at least three consecutive months of procedure records. Patients under 18 years old, with incongruent dates of birth, and with renal transplant or death in the first three months of dialysis were excluded. Each participant in this non-concurrent cohort was followed up from their admission in the year 2000 until one of the following clinical outcomes: transplant, death, permanence in dialysis or study end on 31/Dec/2003.

Socio-demographic, clinical information, and characteristics of the dialysis units were obtained from the National Database for renal replacement therapy. The number of hemodialysis machines and hospital beds in the year 2002 characterized the profile of the patient's city of residence. These data were extracted from the Research on Medical-Sanitary Assistance (http:www.ibge.gov.br/ home/estatistica/populacao/condicaodevida/ ams/default.shtm, accessed on 16/Mar/2010) carried out by the Brazilian Institute of Geography and Statistics (Instituto Brasileiro de Geografia e Estatística - IBGE), and the 2000 Human Development Index (HDI), created by the United Nations Development Program (UNDP) 23.

The dependent variable was the time between the date of admission in the initial modality of treatment up to the date of the transplant. The independent individual variables were demographic characteristics (age and sex); clinical (initial diagnosis of cause of chronic kidney disease 24 , treatment modality - hemodialysis or peritoneal dialysis - number of hospitalizations and length of stay); and outcome (transplant, death, continuity of treatment or followup loss).

Confirmation of transplant occurrence was verified by the issuance of AIH (Hospital Admission Authorizations) for the procedure of renal transplant in the period under study. The initial treatment modality was defined as the first in which the patient remained for at least three consecutive months. Later changes were not considered. Since it was not possible to verify through the waiting list for transplantation, an intention to treat approach was used whereby all patients starting renal replacement therapy were considered to be suitable for placement on the waiting list 8 .

Contextual variables related to the characterization of the renal unit where the patient underwent dialysis were analyzed as follows: (1) through a composite indicator to determine the unit's level of complexity, obtained by means of Principal Component Analysis 25, including the 
variables - unit profile (ambulatory and/or hospital), number of medical offices and the existence of operating rooms for ambulatory surgeries; (2) characterization of the juridical nature (public or private); (3) number of hemodialysis machines; and (4) geographical localization of the renal unit (capital, metropolitan area or interior).

Principal component analysis is a technique that allows the number of variables assessed to be reduced, thereby generating a new set of $p$ variables (denominated principal components) in such a way that the first component is the one that presents the greatest possible variance among all the possible linear combinations of the original variables. The other components are ordered according to their variability ${ }^{25}$. Contextual variables related to the city of residence were: geographic region; location (capital, metropolitan region or interior); number of hemodialysis machines/10,000 inhabitants and number of hospital beds/1,000 inhabitants and, finally, the HDI as a surrogate of the socioeconomic conditions of the cities.

HDI is a universal composite indicator that encompasses three elements: income, education and average life expectancy. Its value ranges from 0 (no human development) to 1 , being 0.600 to 0.699 considered medium-low, 0.700 to 0.799 medium-high and 0.800 to 0.900 high 23 .

Descriptive data analysis was carried out by means of frequency distributions, measures of central tendency and variability for the characteristics under study. For the comparison between transplanted and non-transplanted patients, $\chi^{2}$ test was used for the category and t-Student for the continuous variables. The Kaplan-Meier method was used to estimate the curves up to the occurrence of transplant and the Log-Rank test to compare them according to the categories of the same variable. Percentile 90 of the survival function was estimated through the Bootstrap method 26.

Hierarchical entry of variables was carried out using significant variables $(p<0.20)$ in the univariate analysis (Figure 1). To identify the independent effect of transplant explanatory variables, Cox's multivariate model of proportional risks was used (hazard ratio - HR). Firstly, model 1 was adjusted with the individual variables; then, the contextual variables of the dialysis unit were included in model 2; and lastly, the contextual variables of the patient's city of residence. In this last adjusted model the random effect or fragility of the city's HDI was included 27. The inclusion of this random effect was carried out under the assumption that patients who reside in the same city are exposed to similar health care conditions and public policies. Gamma probability distri- bution was used to estimate the variance of the random effect. Comparison among the models was performed through Wald's tests and likelihood ratio 27 .

The results presented are the estimates with their $95 \%$ confidence interval of the hazard ratio of undergoing transplantation according to the different variables under study. The importance of each covariable in the model was assessed using Wald's test. The assumption of proportionality of risk was assessed by graphic analysis of Schoenfeld residuals 28 . Statistical analyses were carried out through free software R 2.8.1 version (The R Foundation for Statistical Computing, Vienna, Austria; http://www.r-project.org).

The renal replacement therapy project was approved by the Research Ethics Committee at the Federal University of Minas Gerais (decision ETIC 397/2004).

\section{Results}

In the year 2000, 17,084 patients eligible for the study started dialysis in Brazil. Of these, the following were excluded: 607 (3.6\%) patients under 18 years of age, $43(0.25 \%)$ with invalid data for date of birth, 2,323 (13.6\%) patients who died in the first three months of treatment, leaving 14,111 remaining patients for follow up. Of these, $1,701(12 \%)$ received renal transplant during four years of follow up; $1,092(64.2 \%)$ received a kidney from living donors and 609 (35.8\%) from deceased donors.

In Table 1, column 1, the profile of the patients who started dialysis in Brazil in 2000 can be observed. Most of them started treatment in hemodialysis, were male, age range from 45 to 64 years, average age 52 years old. The main determined causes of chronic kidney diseases were hypertension and other cardiovascular diseases, but in $34.7 \%$ of the patients, the diagnosis of the cause was not determined. The patients had on average $1.96 \pm 3.14$ hospitalizations, with an average stay of $7.52 \pm 7.81$ days in hospital.

Regarding the characteristics for units of dialysis, it was possible to establish through principal component analysis eight scoring patterns, grouped in three levels of complexity. Level 1 (lower level of complexity) was attributed to the units that offered ambulatory care, did not have ambulatory operating rooms and had fewer than three medical offices; Level 3 (higher level of complexity) to the units that offered hospital care, had ambulatory operating rooms and more than ten medical offices; and level 2 (intermediate level of complexity) represented the other possibilities of score combinations. In Table 2, 

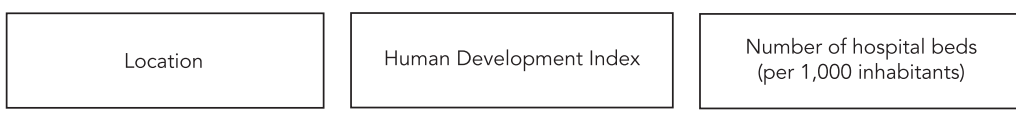

Number of hemodialysis machines (per 10,000 habitants)
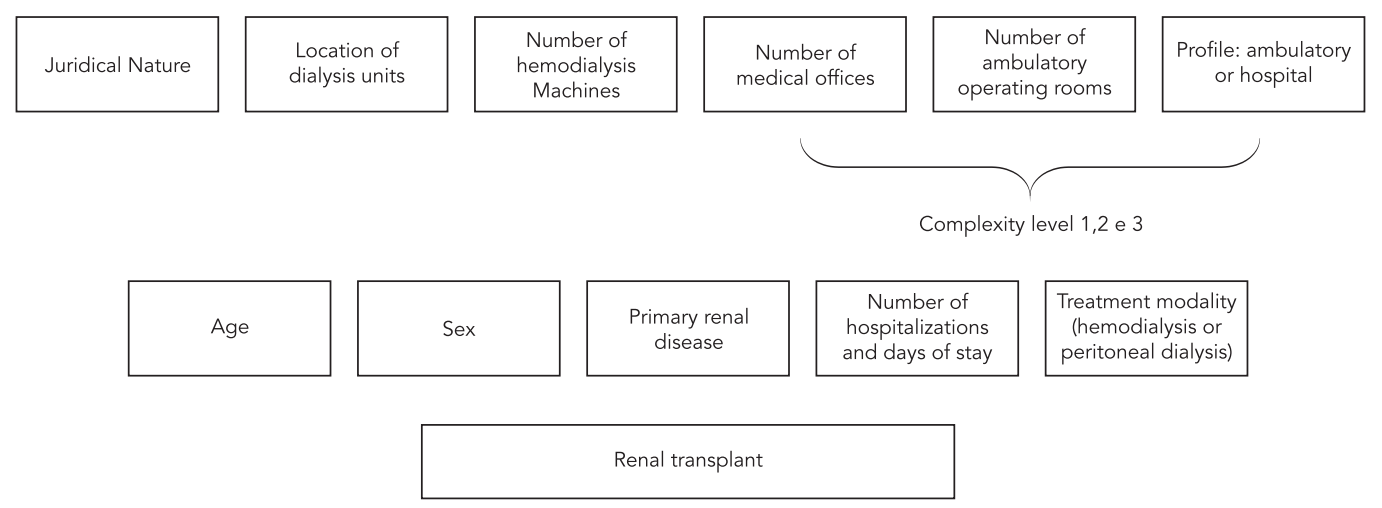

Complexity level 1,2 e 3

column 1, it can be noted that most of the units were level 1, that is, the least complex, private and with up to 20 hemodialysis machines. Because of a high percentage of incomplete data (70\%), the number of hemodialysis machines was not considered in the final principal component analysis, as well as in the multivariate analyses. The legal variable was also excluded, due to its low capacity for explanation (10\%) in principal component analysis.

As for the place of residence, most of the patients were from the Southeast region, from remote cities with high HDI (higher or equal to 0.800 ), with fewer than 3 hospital beds/1,000 inhabitants and at least 1 hemodialysis machine per 10,000 inhabitants.

In columns 2 and 3 of Tables 1 and 2, it can be observed that the transplanted patients were made up of a higher percentage of males, were young, had glomerulonephritis as the cause of chronic kidney diseases and had no record of hospitalizations during follow up. They underwent dialysis at public units, with lower levels of complexity, mostly located in state capitals. They were residents of the Southeast region, in cities with high HDI and with up to 3 hospital beds/1,000 inhabitants.

In Table 3, the 90th percentiles of the waiting time up to kidney graft can be observed. Shorter time was verified for males under 30 years old, under hemodialysis, with glomerulonephritis as the primary renal disease, no occurrence of hospitalizations. Patients from less complex public units, located in capital cities with up to twenty hemodialysis machines and resident in the South or Southeast, in metropolitan areas with higher HDI, also had earlier access to kidney transplantation (Table 3). It was also observed that the patients that received the kidney from a living donor waited an average time of 16.9 months, while those who received it from deceased donors had an average of 24.4 months of waiting.

In Cox's proportional risk model with the individual variables, Model 1 (Table 4), the patients less likely to undergo transplantation were female (19\%); the elderly (94\%); those with diabetes (55\%) and hypertension (33\%); those under peritoneal dialysis treatment (23\%), and with longer stays in hospital ( $36 \%$ and $26 \%$ ) in relation to the other reference categories.

When the contextual variables of the dialysis units were included in Model 2, their complexity level was inversely associated to the risk of transplant. That is, patients who had dialysis in less complex units presented an 18\% higher risk in relation to those in complex units. The patients under treatment in units located in metropolitan areas and in remote cities presented $12 \%$ to $21 \%$ less risk of receiving a renal transplant, respectively.

Finally, when the variables related to the city of residence was included as covariables and HDI 
Socio-demographic and clinical characteristics of incident patients in dialysis. Brazil, 2000.

\begin{tabular}{|c|c|c|c|c|c|c|c|}
\hline \multirow[t]{2}{*}{ Variables } & \multicolumn{2}{|c|}{$\begin{array}{c}\text { Total } \\
(n=14,111)\end{array}$} & \multicolumn{2}{|c|}{$\begin{array}{c}\text { Non transplanted } \\
(n=12,410)\end{array}$} & \multicolumn{2}{|c|}{$\begin{array}{l}\text { Transplanted } \\
(n=1,701)\end{array}$} & \multirow[t]{2}{*}{$p$-value } \\
\hline & $\mathrm{n}$ & $\%$ & $\mathrm{n}$ & $\%$ & $\mathrm{n}$ & $\%$ & \\
\hline \multicolumn{8}{|l|}{ Sex } \\
\hline Male & 8,054 & 57.1 & 7,029 & 56.6 & 1,025 & 67.6 & \multirow[t]{2}{*}{0.005} \\
\hline Female & 6,057 & 42.9 & 5,381 & 43.4 & 603 & 39.7 & \\
\hline \multicolumn{8}{|l|}{ Age group (years) } \\
\hline $18-29$ & 1,437 & 10.2 & 1,017 & 8.2 & 420 & 24.7 & \multirow[t]{4}{*}{0.000} \\
\hline $30-44$ & 3,283 & 23.3 & 2,578 & 20.8 & 705 & 41.4 & \\
\hline $45-64$ & 6,199 & 43.9 & 5,662 & 45.6 & 537 & 31.6 & \\
\hline$\geq 65$ & 3,192 & 22.6 & 3,153 & 25.4 & 39 & 2.3 & \\
\hline Average $\pm \mathrm{SD}$ & \multicolumn{2}{|c|}{$52.0 \pm 16.0$} & \multicolumn{2}{|c|}{$53.6 \pm 15.5$} & \multicolumn{2}{|c|}{$39.8 \pm 12.7$} & 0.000 \\
\hline \multicolumn{8}{|l|}{ Chronic kidney diseases cause } \\
\hline Diabetes mellitus & 2,465 & 17.5 & 2,338 & 18.8 & 127 & 7.5 & \multirow[t]{5}{*}{0.000} \\
\hline Glomerulonephritis & 1,956 & 13.9 & 1,525 & 12.3 & 431 & 25.3 & \\
\hline Hypertension/Cardiovascular & 3,655 & 25.9 & 3,251 & 26.2 & 404 & 23.8 & \\
\hline Undetermined & 4,897 & 34.7 & 4,298 & 34.6 & 599 & 35.2 & \\
\hline Other diseases & 1,138 & 8.1 & 998 & 8.0 & 140 & 8.2 & \\
\hline \multicolumn{8}{|l|}{ Initial modality } \\
\hline Hemodialysis & 12,543 & 88.9 & 10,953 & 88.3 & 1,590 & 93.5 & \multirow[t]{2}{*}{0.000} \\
\hline Peritoneal dialysis & 1,568 & 11.1 & 1,457 & 11.7 & 111 & 6.5 & \\
\hline \multicolumn{8}{|l|}{$\begin{array}{l}\text { Number of hospitalizations during } \\
\text { treatment }\end{array}$} \\
\hline 0 & 6,485 & 46.0 & 5,635 & 45.4 & 850 & 50.0 & \multirow[t]{3}{*}{0.000} \\
\hline $1-2$ & 3,763 & 26.7 & 3,223 & 26.0 & 540 & 31.7 & \\
\hline$\geq 3$ & 3,863 & 27.4 & 3,552 & 28.6 & 311 & 18.3 & \\
\hline Average $\pm \mathrm{SD}$ & \multicolumn{2}{|c|}{$1.96 \pm 3.14$} & \multicolumn{2}{|c|}{$2.04 \pm 3.24$} & \multicolumn{2}{|c|}{$1.33 \pm 2.23$} & 0.000 \\
\hline \multicolumn{8}{|l|}{ Stay in hospital (days/month) } \\
\hline 0 & 6,583 & 46.7 & 5,718 & 46.1 & 865 & 50.9 & \multirow[t]{3}{*}{0.000} \\
\hline $1-2$ & 6,240 & 44.2 & 5,476 & 44.1 & 764 & 44.9 & \\
\hline$>2$ & 1,288 & 9.1 & 1,216 & 9.8 & 72 & 4.2 & \\
\hline \multicolumn{8}{|c|}{ Stay in hospital (days/hospitalization) } \\
\hline Average $\pm \mathrm{SD}$ & \multicolumn{2}{|c|}{$7.52 \pm 7.81$} & \multicolumn{2}{|c|}{$7.77 \pm 8.04$} & \multicolumn{2}{|c|}{$5.53 \pm 5.23$} & 0.000 \\
\hline
\end{tabular}

SD: standard deviation.

Source: National Database in Renal Replacement Therapy (Cherchiglia et al. 21; Queiroz et al. 22).

as random effect in Model 3, the patients residing in metropolitan and remote areas presented a higher likelihood (HR: 1.723) of receiving kidney graft than the patients residing in capitals (HR: 2.647). Since the variable geographic region of residence presented strong association with HDI $\left(\chi^{2}=4892,8 \mathrm{GL}\right)$, the latter was left as random effect in the final model.

When comparing Model 1 with Model 3, it can be verified that the risk estimates according to individual variables (sex, age, basic cause of end-stage chronic renal disease and treatment modality) did not show considerable alterations after the adjustment by the contextual variables.
The risk of receiving transplant for patients in less complex units increased when adjusted by the city variables in $2 \%$. As for the unit's location, the likelihood of not undergoing transplantation for patients who did dialysis in units in the metropolitan region and in the interior increases by $25 \%$ and $36 \%$, respectively, when adjusted by variables for city of residence.

As the HDI random effect was significant (Table 5 and 6), it can be concluded that patients with end-stage chronic renal disease residing in cities with higher HDI were more likely to receive a kidney transplantation in Brazil than those residing in low HDI places. 
Description of context variables from dialysis units and place of residence of incident patients in dialysis. Brazil, 2000.

\begin{tabular}{|c|c|c|c|c|c|c|c|}
\hline \multirow[t]{2}{*}{ Variables } & \multicolumn{2}{|c|}{$\begin{array}{c}\text { Total } \\
(n=14,111)\end{array}$} & \multicolumn{2}{|c|}{$\begin{array}{l}\text { Non-transplanted } \\
\qquad(n=12,410)\end{array}$} & \multicolumn{2}{|c|}{$\begin{array}{l}\text { Transplanted } \\
(\mathrm{n}=1,701)\end{array}$} & \multirow[t]{2}{*}{$\mathrm{p}$-value } \\
\hline & $n$ & $\%$ & $\mathrm{n}$ & $\%$ & $\mathrm{n}$ & $\%$ & \\
\hline \multicolumn{8}{|l|}{ Unit's level of complexity } \\
\hline 1 & 5,178 & 40.1 & 4,345 & 38.7 & 833 & 49.2 & 0.000 \\
\hline 2 & 3,530 & 27.3 & 3,140 & 28.0 & 390 & 23.0 & \\
\hline 3 & 4,203 & 32.6 & 3,732 & 33.3 & 471 & 27.8 & \\
\hline \multicolumn{8}{|l|}{ Juridical nature } \\
\hline Public & 4,369 & 44.1 & 3,334 & 39.5 & 1,035 & 69.9 & 0.000 \\
\hline Private & 5,548 & 55.9 & 5,103 & 60.5 & 445 & 30.1 & \\
\hline \multicolumn{8}{|l|}{ Hemodialysis machines at unit } \\
\hline $0-20$ & 1,523 & 47.7 & 1,003 & 44.7 & 520 & 54.9 & 0.000 \\
\hline $21-30$ & 1,057 & 33.1 & 766 & 34.1 & 291 & 30.7 & \\
\hline$>30$ & 614 & 19.2 & 477 & 21.2 & 137 & 14.5 & \\
\hline \multicolumn{8}{|l|}{ Location of dialysis unit } \\
\hline Capital & 5,815 & 45.0 & 4,940 & 44.0 & 875 & 51.7 & 0.000 \\
\hline Metropolitan region & 2,007 & 15.5 & 1,739 & 15.5 & 268 & 15.8 & \\
\hline Interior & 5,103 & 39.5 & 4,552 & 40.5 & 551 & 32.5 & \\
\hline \multicolumn{8}{|l|}{ Region of residence } \\
\hline Southeast & 7,604 & 53.9 & 6,612 & 53.3 & 992 & 58.3 & 0.000 \\
\hline North & 478 & 3.4 & 420 & 3.4 & 58 & 3.4 & \\
\hline Northeast & 2,965 & 21.0 & 2,728 & 22.0 & 237 & 13.9 & \\
\hline South & 2,288 & 16.2 & 1,975 & 15.9 & 313 & 18.4 & \\
\hline Center-west & 776 & 5.5 & 675 & 5.4 & 101 & 5.9 & \\
\hline \multicolumn{8}{|l|}{ City of residence } \\
\hline Capital & 5,083 & 36.0 & 4,511 & 36.3 & 572 & 33.6 & 0.009 \\
\hline Metropolitan region & 2,736 & 19.4 & 2,363 & 19.0 & 373 & 21.9 & \\
\hline Interior & 6,292 & 44.6 & 5,536 & 44.6 & 756 & 44.4 & \\
\hline \multicolumn{8}{|c|}{ Human Development Index categorized } \\
\hline Medium-low $(\leq 0.699)$ & 1,545 & 10.9 & 1,404 & 11.3 & 141 & 8.3 & 0.001 \\
\hline Medium-high (0.700-0.799) & 5,250 & 37.2 & 4,611 & 37.2 & 639 & 37.6 & \\
\hline High $(\geq 0.800)$ & 7,316 & 51.8 & 6,395 & 51.5 & 921 & 54.1 & \\
\hline \multicolumn{8}{|c|}{ Number of hospital beds (per 1,000 inhabitants) } \\
\hline $0-3$ & 7,155 & 54.3 & 6,258 & 53.9 & 897 & 56.8 & 0.017 \\
\hline$>3$ & 6,025 & 45.7 & 5,343 & 46.1 & 682 & 43.2 & \\
\hline \multicolumn{8}{|c|}{ Number of hemodialysis machines (per 10,000 habitants) } \\
\hline $0-1$ & 5,223 & 37.4 & 4,578 & 37.2 & 645 & 38.4 & 0.187 \\
\hline$>1$ & 8,758 & 62.6 & 7,722 & 62.8 & 1,036 & 61.6 & \\
\hline
\end{tabular}

Source: National Database in Renal Replacement Therapy (Cherchiglia et al. 21; Queiroz et al. 22); Programa das Nações Unidas para o Desenvolvimento/ Instituto de Pesquisa Econômica Aplicada 23; Brazilian Institute of Geography and Statistics (http:www.ibge.gov.br/home/estatistica/populacao/ condicaodevida/ams/default.shtm, accessed on 16/Mar/2010).

The assumption of proportionality of risk was assessed by graphic analysis of Schoenfeld residuals and, with the exception of legal factors which were withdrawn from the final model, all variables did not violate the assumption of proportionality of risk.

\section{Discussion}

The results obtained in this study show differentials in access to transplant according to sociodemographic, clinical, geographic and social factors, indicating that the system of organ allocation has not eliminated avoidable disparities 
Table 3

Time of access (months) to renal transplant for $10 \%$ of patients receiving dialysis in 2000. Brazil, 2000-2003.

\begin{tabular}{|c|c|c|}
\hline Variables & $S(90)$ & p-value \\
\hline \multicolumn{3}{|l|}{ Sex } \\
\hline Male & 23.90 & 0.019 \\
\hline Female & 27.10 & \\
\hline \multicolumn{3}{|l|}{ Age group (years) } \\
\hline $18-29$ & 13.27 & 0.000 \\
\hline $30-44$ & 16.00 & \\
\hline $45-64$ & 35.48 & \\
\hline Over 65 & - & \\
\hline \multicolumn{3}{|l|}{ Chronic kidney diseases cause } \\
\hline Diabetes mellitus & - & 0.000 \\
\hline Glomerulonephritis & 15.24 & \\
\hline Hypertension/Cardiovascular & 27.96 & \\
\hline Undetermined & 25.26 & \\
\hline Other diseases & 27.10 & \\
\hline \multicolumn{3}{|l|}{ Initial modality } \\
\hline Hemodialysis & 24.39 & 0.000 \\
\hline Peritoneal dialysis & 37.72 & \\
\hline \multicolumn{3}{|c|}{ Number of hospitalizations during treatment } \\
\hline 0 & 21.85 & 0.000 \\
\hline $1-2$ & 23.43 & \\
\hline$\geq 3$ & 37.95 & \\
\hline \multicolumn{3}{|l|}{ Stay in hospital (days/months) } \\
\hline 0 & 21.70 & 0.000 \\
\hline $1-2$ & 29.63 & \\
\hline$>2$ & 24.77 & \\
\hline \multicolumn{3}{|l|}{ Unit's complexity level } \\
\hline 1 & 21.42 & 0.000 \\
\hline 2 & 27.53 & \\
\hline 3 & 26.45 & \\
\hline \multicolumn{3}{|l|}{ Juridical nature } \\
\hline Public & 15.87 & 0.000 \\
\hline Private & 45.50 & \\
\hline \multicolumn{3}{|c|}{ Number of hemodialysis machines unit } \\
\hline $0-20$ & 13.49 & 0.000 \\
\hline $21-30$ & 14.42 & \\
\hline$>30$ & 17.25 & \\
\hline \multicolumn{3}{|l|}{ Location of dialysis unit } \\
\hline Capital & 22.18 & 0.000 \\
\hline Metropolitan region & 24.18 & \\
\hline Interior & 28.39 & \\
\hline \multicolumn{3}{|l|}{ Region of residence } \\
\hline Southeast & 23.29 & 0.000 \\
\hline North & 23.79 & \\
\hline Northeast & 38.51 & \\
\hline South & 23.11 & \\
\hline Center-west & 25.03 & \\
\hline
\end{tabular}

(continues) 


\begin{tabular}{|c|c|c|}
\hline Variables & $S(90)$ & p-value \\
\hline \multicolumn{3}{|l|}{ Place of city of residence } \\
\hline Capital & 26.91 & 0.013 \\
\hline Metropolitan region & 22.57 & \\
\hline Interior & 25.00 & \\
\hline \multicolumn{3}{|c|}{ Human Development Index categorized } \\
\hline Medium-low ( $\leq 0.699)$ & 32.82 & 0.001 \\
\hline Medium-high (0.700-0.799) & 25.46 & \\
\hline High $(\geq 0,800)$ & 24.34 & \\
\hline \multicolumn{3}{|c|}{ Number of hospital beds (per 1,000 inhabitants) } \\
\hline $0-3$ & 24.53 & 0.112 \\
\hline$>3$ & 27.07 & \\
\hline \multicolumn{3}{|c|}{ Number of hemodialysis machines (per 10,000 inhabitants) } \\
\hline $0-1$ & 24.66 & 0.456 \\
\hline$>1$ & 25.54 & \\
\hline
\end{tabular}

Source: National Database in Renal Replacement Therapy (Cherchiglia et al. 21; Queiroz et al. 22); Programa das Nações Unidas para o Desenvolvimento/Instituto de Pesquisa Econômica Aplicada 23; Brazilian Institute of Geography and Statistics (http:www.ibge.gov.br/home/estatistica/populacao/condicaodevida/ams/default.shtm, accessed on 16/Mar/2010).

for those competing for an organ in the national waiting list. This study, based on the integration of several databases obtained from the SUS, shows that only $12 \%$ of Brazilian patients in renal replacement therapy received kidney transplantation over four years of follow up. This is a higher figure when compared to the State of Rio de Janeiro, where only $6.3 \%$ of patients managed to get a renal transplant between 1998 and 2002 29, contrasting to the city of Belo Horizonte in the Minas Gerais State, where $22.7 \%$ of patients registered on the waiting list from 2000 to 2004 received transplant 30 .

In terms of absolute numbers of transplants, Brazil ranks second in the world. Nevertheless, when the country's population is considered, it drops to tenth. It has a rate of renal transplants of 18 people per million members of the population, a lower rate compared to other countries like Spain (48 per million), the USA (48), Portugal (36) and Canada (35) 5. Brazil has been gradually increasing the number of donations. However there has been no effective reduction in the waiting list, but rather an increase of it, despite the increased number of renal transplants (http:// www.saude.gov.br/transplantes/, accessed on 16/Mar/2010). The increase in the demand for a kidney in Brazil and the significant growth of the waiting lists result in longer waiting time. Consequently, the burden of comorbidities in patients who need transplant has increased, and it is important to ensure that these patients have equitable access to this procedure.
From the initial times of organ transplants to the present day, the process of transplanting has made considerable development in terms of techniques, results, variety of transplanted organs and number of procedures performed. However, the legislation on transplants in Brazil is relatively recent 19,20 . The national policies on organ and tissue transplants are based on the Legislation (Law $n^{\circ}$. 9.434/97 and Law $n^{o}$. 10.211/01 - http://www.saude.gov.br/trans plantes/, accessed on 16/Mar/2010), including within their guidelines: donations that are free of charge, beneficence in relation to those who receive them, and non-maleficence with regard to living donors. All are based on the principles of universality, integrality and equality and in accordance with Article 198 of the 1988 Federal Constitution.

Although the present legislation claims integrality in care for end-stage chronic renal disease patients and equity in the access to transplants, the results herein obtained suggest the existence of iniquities in the organ allocation system in Brazil. There were found to be different degrees of accessibility to renal transplant in the country, depending on the individual's characteristics, the context of the dialysis unit and the place of residence. Greater probability of access was observed for male patients, the youngest, those for whom the basic cause of end-stage chronic renal disease was different from diabetes and arterial hypertension, those under hemodialysis and with a shorter period of 
Table 4

Multivariate Cox proportional hazards model for renal transplant. Brazil, 2000-2003.

\begin{tabular}{|c|c|c|c|c|c|c|}
\hline \multirow[t]{2}{*}{ Variables } & \multicolumn{2}{|c|}{ Model 1} & \multicolumn{2}{|c|}{ Model 2} & \multicolumn{2}{|c|}{ Model 3} \\
\hline & HR & $95 \% \mathrm{Cl}(\mathrm{HR})$ & HR & $95 \% \mathrm{Cl}(\mathrm{HR})$ & $\mathrm{HR}$ & $95 \% \mathrm{Cl}(\mathrm{HR})$ \\
\hline \multicolumn{7}{|l|}{ Fixed part } \\
\hline \multicolumn{7}{|l|}{ Individual variables } \\
\hline \multicolumn{7}{|l|}{ Sex } \\
\hline Male & 1.000 & - & 1.000 & - & 1.000 & - \\
\hline Female & 0.812 & $0.737 ; 0.895$ & 0.812 & $0.736 ; 0.896$ & 0.812 & $0.737 ; 0.896$ \\
\hline \multicolumn{7}{|l|}{ Age group (years) } \\
\hline $18-29$ & 1.000 & - & 1.000 & - & 1.000 & - \\
\hline $30-44$ & 0.753 & $0.667 ; 0.851$ & 0.757 & $0.670 ; 0.856$ & 0.736 & $0.651 ; 0.832$ \\
\hline $45-64$ & 0.344 & $0.301 ; 0.393$ & 0.356 & $0.312 ; 0.407$ & 0.348 & $0.304 ; 0.397$ \\
\hline Over 65 & 0.056 & $0.040 ; 0.078$ & 0.062 & $0.045 ; 0.086$ & 0.060 & $0.043 ; 0.084$ \\
\hline \multicolumn{7}{|l|}{ Chronic kidney diseases cause } \\
\hline Glomerulonephritis & 1.000 & - & 1.000 & - & 1.000 & - \\
\hline Diabetes mellitus & 0.453 & $0.370 ; 0.556$ & 0.451 & $0.367 ; 0.554$ & 0.439 & $0.357 ; 0.539$ \\
\hline Hypertension/Cardiovascular & 0.670 & $0.584 ; 0.770$ & 0.665 & $0.579 ; 0.764$ & 0.669 & $0.582 ; 0.769$ \\
\hline Undetermined & 0.747 & $0.659 ; 0.847$ & 0.738 & $0.651 ; 0.838$ & 0.704 & $0.620 ; 0.799$ \\
\hline Other diseases & 0.710 & $0.587 ; 0.861$ & 0.723 & $0.596 ; 0.876$ & 0.704 & $0.581 ; 0.853$ \\
\hline \multicolumn{7}{|l|}{ Initial modality } \\
\hline Hemodialysis & 1.000 & - & 1.000 & - & 1.000 & - \\
\hline Peritoneal dialysis & 0.771 & $0.636 ; 0.936$ & 0.804 & $0.661 ; 0.977$ & 0.767 & $0.631 ; 0.932$ \\
\hline \multicolumn{7}{|l|}{ Stay in hospital (days/month) } \\
\hline 0 & 1.000 & - & 1.000 & - & 1.000 & - \\
\hline $1-2$ & 0.642 & $0.583 ; 0.709$ & 0.665 & $0.602 ; 0.735$ & 0.662 & $0.600 ; 0.731$ \\
\hline$>2$ & 0.738 & $0.580 ; 0.939$ & 0.777 & $0.609 ; 0.992$ & 0.778 & $0.609 ; 0.994$ \\
\hline \multicolumn{7}{|l|}{ Context variable of the unit } \\
\hline \multicolumn{7}{|l|}{ Unit's complexity level } \\
\hline 1 & & & 1.175 & $1.047 ; 1.318$ & 1.190 & $1.065 ; 1.336$ \\
\hline 2 & & & 0.918 & $0.802 ; 1.050$ & 0.955 & $0.834 ; 1.093$ \\
\hline 3 & & & 1.000 & - & 1.000 & - \\
\hline \multicolumn{7}{|l|}{ Location of dialysis unit } \\
\hline Capital & & & 1.000 & - & 1.000 & - \\
\hline Metropolitan Region & & & 0.877 & $0.764 ; 1.006$ & 0.631 & $0.530 ; 0.751$ \\
\hline Interior & & & 0.793 & $0.712 ; 0.884$ & 0.426 & $0.363 ; 0.501$ \\
\hline \multicolumn{7}{|l|}{ Context variables of the city } \\
\hline \multicolumn{7}{|l|}{ Location of city of residence } \\
\hline Capital & & & & & 1.000 & - \\
\hline Metropolitan Region & & & & & 1.723 & $1.452 ; 2.045$ \\
\hline Interior & & & & & 2.647 & $2.223 ; 3.153$ \\
\hline \multicolumn{7}{|l|}{ Random part } \\
\hline \multicolumn{7}{|l|}{ Human Development Index city } \\
\hline Variance of random effect & & & & & 0.886 & \\
\hline Qui-square (p-value) & & & & & 76.31 & 0.000 \\
\hline I-likelihood & & & & & -14845.3 & \\
\hline Wald's test & 760 & & 771 & & 920 & \\
\hline $\mathrm{R}^{2}$ & 0.070 & & 0.076 & & 0.086 & \\
\hline Adjustment quality & $1,030(11)$ & & $1,017(15)$ & & $1,156(19)$ & \\
\hline
\end{tabular}

HR: hazard ratio; 95\% Cl: 95\% confidence interval.

Source: National Database in Renal Replacement Therapy (Cherchiglia et al. 21; Queiroz et al. 22); Programa das Nações Unidas para o Desenvolvimento/ Instituto de Pesquisa Econômica Aplicada 23. 
Estimate of the hazard ratio (HR) of renal transplant for city residents, according to Human Development Index (HDI).

Brazil, 2000-2003.

\begin{tabular}{lccc}
\hline HDI & HR estimates & 95\%Cl (HR) & p-value \\
\hline Medium-low $(\leq 0.699)$ & 0.587 & $0.200 ; 1.721$ & 0.000 \\
Medium-high $(0.700-0.799)$ & 1.032 & $0.355 ; 3.001$ & $0.475 ; 4.014$ \\
High $(\geq 0.800)$ & 1.381 & & \\
\hline
\end{tabular}

95\% Cl: 95\% confidence interval.

Source: National Database in Renal Replacement Therapy (Cherchiglia et al. 21; Queiroz et al. 22); Programa das Naçõrs Unidas para o Desenvolvimento/Instituto de Pesquisa Econômica Aplicada 23.

stay in hospital. In addition to these, there was found to be an important influence from the patient's place of dialysis and their residence, factors which point to individual, social and geographic inequalities. Similar disproportions have also been identified in the USA, Canada and Europe 8,9,10,11,12,13,14,15,16,17,18.

Older patients presented longer waiting time and are less likely to undergo transplantation. An older patient's clinical conditions and higher comorbidity are counter-indications for transplant surgery ${ }^{8}$. Some authors report that older people prefer to remain in dialysis as opposed to being submitted to transplant 31 , but they also have more difficulty in finding a living donor 32 . In Brazil, although age is not an absolute criterion for counter-indication for transplants, the difference observed shows that it may be an important ranking criterion for the individual when it comes to choosing the waiting list for renal transplant 29 .

Sex is considered to be an important determinant for accessing a waiting list for kidney graft. Women have a lower probability of being included on the waiting list 8,10,11,12. Explanations for these disparities include socioeconomic and health status, sex selection by health professionals, patient preference, non-compliance and sex based differences in family preferences for transplantation 13,14,33. However, access to the waiting list was not assessed in this study. Other studies also reported disparities in kidney distribution, despite the fact that women represent the majority of living donors 34 . A probable reason is the fact that women have a high level of panel reactive antibodies induced by pregnancy, which counter-indicates them for transplant 10,11 . New investigations need to clarify whether these differences occur in the access to the waiting list and in relation to the type of donor in Brazil.

Patients with diabetes have the lowest rate of access to transplantation, as observed for pa- tients from Rio de Janeiro ${ }^{29}$. Diabetes is known to be a strong limiter for transplant, followed by hypertension, two comorbidities that are highly prevalent in elderly people, which corroborates the hypothesis that elderly people and diabetics have a lesser chance of receiving a transplant 8,29 . Patients with diabetes present a lower rate of access to the waiting list and to the transplant, which may be due to additional and more serious comorbidities, limiting their access to renal transplant and, probably, their survival 7,8. In the present study, less than $10 \%$ of them managed to obtain a transplant.

Although this study did not assess information on comorbidities, it was possible to obtain the number of hospitalizations and the average number of days of stay in hospital per hospitalization, an indirect measure of the clinical conditions of the patient in dialysis. It was verified that patients with a greater number of days in hospital presented lower risk of transplant. One possibility is the fact that these patients present worse clinical conditions and are not eligible for transplant. Despite the technical advances in medical care and dialysis treatment, morbidity and mortality are still high in patients with end-stage chronic renal disease. Several factors contribute to medical complications such as the high prevalence of cardiovascular disease, protein-energy malnutrition, and infections of the arteriovenous fistula. Underlying disease is also an important determinant for prognosis, with diabetics and elderly people presenting an excess of morbidity and mortality 35 .

An important effect of the dialysis unit profile was verified. Patients in units considered to be less complex presented a higher risk of receiving a kidney, a result that is in disagreement with other investigations in which access to renal transplant was associated with the clinic's characteristics such as: bigger size, large volume of inclusions in the list, better organizational aspects, skilled 
professionals in relation to transplant and placement in a hospital with transplant center 8,13 . A possible explanation would be the fact that the ambulatory units receive patients in better clinical conditions. Some authors point to the fact that the lack of suitable facilities in ambulatory units makes it difficult to deal with sicker patients since many of them present cardiovascular diseases, a strong predictor of morbidity and mortality. In this way, patients having dialysis in hospital units are sicker, with a high level of dependence, higher risk of death and, therefore, with less possibility of having a transplant 36 .

An important characteristic of the unit predictor of access to transplant was the fact that it was located in a state capital. Units located in state capitals and large urban centers present greater technological density. Therapeutic procedures and the highest levels of Brazilian health technology are concentrated in these strategic locations 37 , in addition to their being closer to transplant centers. Another possibility for this association could be the fact that, in the state capitals, the transplant rate is invariably higher as the population assisted by the units and hospitals is greater than the real population (Registro Brasileiro de Transplante. http://www.abto. org.br/abtov02/portugues/população/rbt/an oXV_n4/index.aspx?idCategoria $=2$, accessed on 15/Apr/2010).

Another important factor in the access to renal transplant was the patient's geographic area of residence. Unlike what was observed for dialysis units, patients residing in metropolitan regions and in remote areas present higher risk of transplant. Studies have shown geographic disparities in the access to renal transplant among the regions of several countries. These disparities result from distinct experiences and criteria used by the transplant teams to list the patient and distribute the organ, differences in the listing and allocation guidelines of each region of the country and differentiated activities in searching for organs 16,17. Such justifications may not be applied to Brazil since the criteria for registration and organ distribution are standardized. In order to verify the application of the transplant legislation, nationwide studies would be necessary to investigate the possibility of regional differences. In the search for possible explanations for the results herein obtained, the differences in age profile and causes of end-stage chronic renal disease among patients residing in capitals, metropolitan regions and in the interior were verified. Although no significant differences were found for age, a greater percentage of patients with glomerulonephritis in remote areas (16\%) and in metropolitan regions (13\%) compared to state capitals $(12 \%)$ was observed. On the other hand, a greater percentage of diabetes as cause of end-stage chronic renal disease was observed for state capital residents (19\%) when compared to residents of metropolitan regions (18\%) and remote areas (16\%). This could be the probable reason for the differential of risk of transplant for patients according to their region of residence, since patients with glomerulonephritis as basic cause of end-stage chronic renal disease are a risk group for transplant, unlike patients with diabetes.

Our results indicate that patients residing in cities with a higher HDI have more access to renal transplant. As HDI measures the level of human development based on indicators for education (literacy and school registration rate), longevity (life expectancy at birth) and income (Gross Domestic Product - GDP per capita), this may suggest that patients from these cities have a greater probability of transplant due to factors related to access to health care services, besides others such as income and schooling 23.

In a study on time up to transplant and death in Rio de Janeiro 29, there was found to be a large number of people who had undergone transplant but had not been registered or referred $(59.3 \%)$ to transplant by the specialist. Such findings point to both the great fragility of the transplant system, and the need to guarantee better quality of patients' registration within the APAC system. In the present study, $87.2 \%$ of patients had no information about registration in the national waiting list in the APAC. Of the 1,701 transplanted patients, there was information about registration in the national waiting list for only 358 (21\%). It thus confirms the need to improve the quality of the patients' registration in the APAC system.

The administrative data systems, whose purpose is revenues and not research, and from which the National Database in renal replacement therapy originated, may have incomplete, inconsistent or inexistent information 21,22. Such characteristics limit the possibility of making further inferences. Thus, one limitation is the absence of economic and social information (race, education and income) and clinical data (comorbities), essential to assessing equity in the access to transplant. Furthermore, the high proportion of undetermined causes (34.7\%) stands out, which affects the distribution and analysis of causes of end-stage chronic renal disease. As for information about the performance of transplants, despite the use of data from the administrative system, its coverage is reliable since $95 \%$ of these procedures are performed by the SUS 7 . In relation to hospitalizations, in spite of the pos- 
sibility of the patient having been hospitalized through private health insurance, it is important to point out that the SIH covers $70 \%$ to $80 \%$ of hospitalizations in the country, which is a high percentage 38 .

Since the data were not analyzed by type of donor organ separately, it was not possible to verify whether the iniquities are the same when comparing living and deceased donors. Studies stratifying the risks are necessary to verify separately the probabilities of receiving a renal transplant according to type of donor, a proposal for future studies.

Health, disease and death present an individual and collective dimension and are related to socio-economic, cultural, environmental and subjective factors. Besides, individuals and population groups are unequally submitted to protective and risk factors, generating iniquities in the population's health 39,40 . Disparities in health may be defined as "potentially avoidable differences in health (or in health risks that policy can influence) between groups of people who are more and less advantaged socially; these differences sys- tematically place socially disadvantaged groups at further disadvantage on health" 41 (p. 180).

Disparities in the access and results of transplants may threaten the public's confidence in the allocation system and thus reduce the number of organs available for transplant. Scarcity of organs worsens the disparities in the access to transplants and the results. Therefore, understanding and attenuating these disparities and their contributing factors is essential to improve transplant results 42 .

The principle of integrality 6 ensures access not only to all levels of health care, but it also means that access must be guaranteed to all existing technological resources for restoring a patient's health. However, a challenge that presents itself at the moment is the guarantee of access to all high complexity services. Due to the concentration of offer, the high costs involved, the high technological density necessary and the scarcity of specialized professionals, renal transplant requires care at all three government levels (municipal, state and federal) in order to guarantee equity.

\section{Resumo}

O objetivo deste estudo é analisar os fatores individuais e contextuais associados ao acesso ao transplante renal no Brasil. Realizou-se um estudo observacional, prospectivo, não concorrente, a partir de dados da Base Nacional em terapias renais substitutivas, no Brasil. Foram incluídos pacientes incidentes em diálises entre 01/jan/2000 e 31/dez/2000, acompanhados até o transplante, óbito ou final de 2003. Variáveis individuais (idade, sexo, região de residência, doença renal primária, internações) de contexto da unidade de diálise (nível de complexidade, natureza jurídica, máquinas de hemodiálise e localização) e do município (região geográfica, localização e Índice de Desenvolvimento
Humano) foram analisadas. Ajustaram-se modelos de riscos proporcionais com entrada hierárquica para identificar fatores associados ao risco de transplante. Os resultados apontam diferenciais no acesso segundo fatores sociodemográficos, clínicos, geográficos e sociais ao transplante, indicando que o sistema de alocação de órgão não tem eliminado disparidades evitáveis para aqueles que concorrem a um órgão na lista de espera única.

Transplante de Rins; Desigualdades em Saúde; Acesso aos Serviços de Saúde; Falência Renal Crônica 


\section{Contributors}

E. L. Machado was responsible for project design, data analysis and interpretation and writing of the article. W. T. Caiaffa participated in the design, planning and relevant critical revision of the intellectual content and final approval of the version to be published. C. C. César collaborated through data analysis and interpretation and final approval of the version to be published. I. C. Gomes participated in data analysis and final approval of the version to be published. E. I. G. Andrade and F. A. Acúrcio contributed through critical revision of the content and final approval of the version to be published. M. L. Cherchiglia was responsible for design and planning and relevant critical revision of the intellectual content and final approval of the version to be published

\section{Acknowledgments}

The authors are grateful to Daniele Araújo Campo Szuster and Gisele Macedo da Silva, and all the members of the UFMG Research Group on Health Economics for their contribution in the composition of the RRT National Database; and to the financial support from the National Health Fund (Fundo Nacional de Saúde) at the Brazilian Ministry of Health (accord number 4864/2005), CNPq, (process 409729/2006-0)

\section{References}

1. Xue JL, Ma JZ, Louis TA, Collins AL. Forecast of the number of patient with end-stage renal disease in the United States to the year 2010. J Am Soc Nephrol 2001; 12:2753-8.

2. Port FK, Wolfe RA, Mauger EA, Berling DP, Jiang K. Comparison of survival probabilities for dialysis patients vs cadaveric renal transplantation recipients. JAMA 1993; $270: 1339-43$.

3. Evans RW, Manninen DL, Garrison LP, Hart LG, Blagg CR, Gutman RA, et al. The quality of life of patients with end-stage renal disease. N Engl J Med 1985; 312:553-9.

4. Eggers PW. Effect of transplantation on the Medicare end-stage renal disease program. N Engl J Med 1988; 318:223-9.

5. Medina-Pestana JO, Vaz MLS, Park SI, Garcia VD, Abbud-Filho M, Campos HH. Organ transplantation in Brazil in the year 2002. Transplant Proc 2004; 36:799-801.

6. Cunha JP, Cunha RE. Sistema Único de Saúde princípios. In: Campos FE, Tonon LM, Oliveira Júnior M, editors. Planejamento e gestão em saúde. Belo Horizonte: Coopemed; 1988. p. 13-25. (Cadernos de Saúde, 1).

7. Sesso R. Epidemiologia da doença renal crônica no Brasil e sua prevenção. Secretaria de Estado de Saúde de São Paulo http:/ /ftp.cve.saude.sp.gov.br/ doc_tec/cronicas/irc_prevprof.pdf. (accessed on 20/Apr/2010).
8. Oniscu GC, Schalkwijk AAH, Johnson RJ, Brown H, Forsythe JLR. Equity of access to renal transplant waiting list and renal transplantation in Scotland: cohort study. BMJ 2003; 327:1261.

9- Schaeffner ES, Mehta J, Winkelmayer WC. Educational level as a determinant of access to and outcomes after kidney transplantation in the United States. Am J Kidney Dis 2008; 51:811-8.

10. Wolfe RA, Ashby VB, Milford EL, Bloembergen WE, Agodoa LYC, Held PJ, et al. Differences in access to cadaveric renal transplantation in the United States. Am J Kidney Dis 2000; 36:1025-33.

11. Thamer M, Henderson SC, Ray NF, Rinehart CS, Greer JW, Danovitch GM. Unequal acess to cadaveric kidney transplantation in California based on insurance status. Health Serv Res 1999; 34:879-900.

12. Alexander GC, Ashwini R, Sehgal MD. Barriers to cadaveric renal transplantation among blacks, women, and the poor. JAMA 1998; 280:1148-52.

13. Kasiske BL, London W, Ellison MD. Race and socioeconomic factors influencing early placement on the kidney transplant waiting list. J Am Soc Nephrol 1998; 9:2142-7.

14. Ayanian JZ, Cleary PD, Weissman JS, Epstein AM. The effect of pacients' preferences on racial differences in access to renal transplantation. $N$ Engl J Med 1999; 341:1661-9. 
15. Cass A, Cunningham J, Snelling P, Ayanian JZ. Late referral to a nephrologist reduces access to renal transplantation. Am J Kidney Dis 2003; 42:1043-9.

16. Ellison MD, Edwards LB, Edwards EB, Barker CF. Geographic differences in access to transplantation in the United States. Transplantation 2003; 76:1389-94.

17. O'hare AM, Johansen KL, Rodriguez RA. Dialysis and kidney transplantation among patients living in rural areas of the United States. Kidney Int 2006; 69:343-9.

18. Hall YN, O'Hare AM, Young BA, Boyko EJ, Chertow GM. Neighborhood poverty and kidney transplantation among US Asians and Pacific Islanders with end-stage renal disease. Am J Transplant 2008; 8:2402-9.

19. Secretaria de Assistência a Saúde. Política Nacional de Atenção ao Portador de Doença Renal. Brasília: Ministério da Saúde; 2004.

20. Secretaria de Fiscalização e Avaliação de Programas de Governo, Tribunal de Contas da União. Avaliação do TCU sobre o Programa Doação, Captação e Transplante de Órgãos e Tecidos. http:// portal2.tcu.gov.br/portal/pls/portal/docs/690420. PDF (accessed on 16/Jan/2010).

21. Cherchiglia ML, Guerra Júnior AA, Andrade EIG, Machado CJ, Acúrcio FA, Meira Júnior W, et al. A construção da base de dados nacional em terapia renal substitutiva (TRS) centrada no indivíduo: aplicação do método de linkage determinísticoprobabilístico. Revista Brasileira de Estudos de População 2007; 24:163-7.

22. Queiroz OV, Guerra Júnior AA, Machado CJ, Andrade EIG, Meira Júnior W, Acúrcio FA, et al. A construção da Base Nacional em Terapia Renal Substitutiva (TRS) centrada no indivíduo: relacionamento entre registros de óbitos do subsistema de Autorização de Procedimentos de Alta Complexidade (APAC) e pelo Sistema de Informações de Mortalidade (SIM). Epidemiol Serv Saude 2009; 18:107-20.

23. Programa das Nações Unidas para o Desenvolvimento/Instituto de Pesquisa Econômica Aplicada. Atlas do desenvolvimento humano no Brasil. Brasília: Programa das Nações Unidas para o Desenvolvimento/Instituto de Pesquisa Econômica Aplicada; 2000.

24. Organização Mundial da Saúde. Classificação estatística internacional de doenças e problemas relacionados à saúde, 10ạ revisão. 8a Ed. São Paulo: Edusp; 2000.

25. Mingoti SA. Análise de dados através de métodos de Estatística multivariada: uma abordagem aplicada. Belo Horizonte: Editora UFMG; 2005.

26. Akritas MG. Bootstrapping the Kaplan-Meier estimator. J Am Stat Assoc 1986; 81:1032-8.

27. Carvalho MS, Andreozzi VL, Codeço CT, Barbosa MTS, Shimakura SE. Fragilidade. In: Carvalho MS, Andreozzi VL, Codeço CT, Barbosa MTS, Shimakura SE, editors. Análise de sobrevida: teoria e aplicações em saúde. Rio de Janeiro: Editora Fiocruz; 2005. p. 313-344.
28. Colosimo EA, Giolo SR. Análise de sobrevivência aplicada. São Paulo: Edgard Blücher; 2006.

29. Cunha CB, León ACP, Schramm JMA, Carvalho MS, Souza Júnior PRB, Chain R. Tempo até o transplante e sobrevida em pacientes com insuficiência renal crônica no Estado do Rio de Janeiro, Brasil, 1998-2002. Cad Saúde Pública 2007; 23:805-13.

30. Machado EL, Cherchiglia ML, Acúrcio FA. Perfil e desfecho clínico de pacientes em lista de espera por transplante renal, Belo Horizonte/MG, 20002005. Ciên Saúde Coletiv 2009; in press.

31. Gordon EJ. Patient's decisions for treatment of end-stage renal disease and their implications for access to transplantation. Soc Sci Med 2001; 53:971-87.

32. United States Renal Data System. VII- Renal transplantation access and outcomes. Am J Kidney Dis 1997; 30(2 Suppl 1):S118-27.

33. Klassen AC, Hall AG, Saksvig B, Curbow B, Klassen DK. Relationship between patient's perceptions of disadvantage and discrimination and listing for kidney transplantation. Am J Public Health 2002; 92:811-7.

34. Garg PP, Furth SL, Fivush BA, Powe NR. Impact of gender on access to the renal transplant waiting list for pediatric and adult patients. J Am Soc Nephrol 2000; 11:958-64.

35. Locatelli F, Del Vecchio L, Manzoni C. Morbidity and mortality on maintenance haemodialysis. Nephron 1998; 80:380-400.

36. Teo BW, Ma V, Xu H, Li J, Lee EJ. Profile of hospitalisation and death in the first year after diagnosis of end-stage renal disease in a multi-ethnic Asian population. Ann Acad Med Singapore 2010; 39: 79-87.

37. Vianna SM, Nunes A, Góes G. Atenção de alta complexidade no SUS: desigualdades no acesso e no financiamento. Brasília: Ministério da Saúde/Instituto de Pesquisas Econômicas Aplicada; 2005.

38. Almeida MF. Descentralização de sistemas de informação e o uso das informações a nível municipal. Inf Epidemiol SUS. 1998; 7:27-33.

39. Prata PR. Desenvolvimento econômico, desigualdade e saúde. Cad Saúde Pública 1994; 10:387-91.

40. Comissão de Determinantes Sociais da Saúde. Rumo a um modelo conceitual para análise e ação sobre os determinantes sociais de saúde. http:// www.determinantes.fiocruz.br/pdf/texto/ (accessed on 16/Oct/2006).

41. Braveman P. Health disparities and health equity:conce s and measurement. Annu Rev Public Health 2006; 27:167-94.

42. Siminoff LA, Burant CJ, Ibrahim SA. Racial disparities in preferences and perceptions regarding organ donation. J Gen Intern Med 2006; 21:9951000.

Submitted on 16/Jun/2010

Final version resubmitted on 24/Aug/2010

Approved on 10/Sep/2010 